до обраної програми без відриву від виконання ними професійних обов' язків за місцем їх проживання [2].

Основними завданнями дистанційного навчання у ЗПО є: розширення можливостей доступу різних категорій фахівців до якісного навчання за програмами післядипломної освіти; збільшення кількості фахівців, що проходять навчання, при зменшенні витрат на навчання; індивідуалізація процесу навчання; підвищення ефективності навчання слухачів шляхом застосування сучасних інформаційно-комунікаційних технологій; забезпечення контролю якості післядипломної освіти.

Положення про дистанційне навчання у закладах післядипломної освіти також передбачає та освітлює такі питання, як особливості організації дистанційного навчання у ЗПО; забезпечення дистанційного навчання у ЗПО (нормативно-правове, науково-методичне, кадрове, системотехнічне та фінансове).

В усьому світі для дистанційної післядипломної освіти використовується міжнародна система Moodle. Moodle-це спеціалізоване програмне забезпечення, що є платформою підтримки дистанційного навчання (e-learning платформа). Фахівці дистанційного навчання повинні мати відповідні документи, які підтверджують їх кваліфікацію $з$ дистанційного навчання, тому адміністрація Харківської медичної академії післядипломної освіти прийняла рішення про підготовку викладачів академії для проведення дистанційної форми навчання слухачів. Двадцять викладачів академії пройшли навчання у навчально-методичному комплексі Національного технічного університету “КПI" МОН України з питань створення навчальних програм у дистанційному форматі та отримали відповідні свідоцтва.

Висновок. Дистанційна освіта сприяє розширенню можливостей доступу фахівців до навчання, збільшенню кількості лікарів, що проходять навчання, при зменшенні витрат, підвищенню ефективності навчання слухачів. Дистанційна освіта - це близьке майбутнє сучасних освітянських технологій.

\title{
Література
}

1. Про удосконалення післядипломної освіти лікарів : наказ МОЗ України № 1088 від 10.12.2011 p.

\section{СУЧАСНІ ПДХОДИ ДО ПІДВИЩЕННЯ ЯКОСТІ ОСВІТИ У СИСТЕМІ ПІСЛЯДИПЛОМНОї ОСВІТИ}

\author{
О. М. Хвисюк, В. Г. Марченко, В. В. Жеребкін, О. В. Грищенко, І. А. Жадан, \\ К. І. Бодня, Т. Д. Звягінцева, І. А. Соболєва \\ Харківська медична академія післядипломної освіти
}

\section{THE MODERN APPROACHES TO THE INCREASE OF EDUCATIONAL QUALITY IN THE SYSTEM OF POST-GRADUATE EDUCATION}

\author{
O. M. Khvysiuk, V. H. Marchenko, V. V. Zherebkin, O. V. Hryshchenko, I. A. Zhadan, \\ K. I. Bodnya, T. D. Zviahintseva, I. A. Sobolieva \\ Kharkiv Medical Academy of Post Graduate Education
}

\begin{abstract}
Якісне післядипломне навчання лікарів можливе лише за умов безперервного навчання, що базується на усіх досягненнях світової медичної науки та використанні всіх сучасних освітянських технологій.
\end{abstract}

() О. М. Хвисюк, В. Г. Марченко, В. В. Жеребкін та ін. 
The qualified post-graduate education of the doctors is possible only in the condition of the uninterrupted training, that is based on all the achievements of the world medical science and use of all the modern educational technologies.

Скажи мені - і я забуду.

Покажи мені- - я запам'ятаю.

Дозволь мені зробити - і ие стане моїм назавжди.

Китайська мудрість

Вступ. Процес навчання є багатокомпонентним, що дає змогу фахівцю постійно вдосконалюватися. Людина навчається протягом усього життя в усіх сферах життєдіяльності, але найважливішим є наше професійне зростання, яке ніколи не зупиняється. Виходячи з цього, в Україні була прийнята Концепція безперервної освіти, що полягає в стимулюванні у фахівців розуміння необхідності постійного фахового зростання. Сучасний темп розвитку клінічних, лабораторних знань, удосконалення діагностичних засобів та лікувально-діагностичної апаратури веде до того, що для надання допомоги хворим на сучасному рівні фахівець повинен мати уяву іпевний рівень знань та вмінь, щоб відповідати сучасним вимогам медичної науки.

Важливою складовою покращення рівня медичних послуг в країні є система післядипломної освіти лікарів. Після закінчення вищого навчального закладу фахівець отримує мінімум уявлень, знань та вмінь щодо великої кількості медичних напрямів. Після вибору свого особистого шляху починається поглиблене вдосконалення усього набутого раніше, а також отримання багатьох додаткових знань та вмінь, яке продовжується протягом усього життя. Виходячи 3 цього, особливого значення набуває якість надання знань та вмінь у післядипломній освіті. Післядипломна освіта створює умови для безперервності та наступності освіти і включає: перепідготовку, спеціалізацію, розширення профілю, стажування. Особа, яка пройшла перепідготовку і успішно пройшла державну атестацію, а також успішно пройшла стажування або спеціалізацію чи розширила профіль (підвищила кваліфікацію), отримує відповідний документ про післядипломну освіту.

Протягом останніх десятиліть кардинально змінилася система генерації й передачі знань, а їх обсяг багаторазово зріс. На жаль, провідним видом навчання в системі охорони здоров'я лишаються заняття в класній кімнаті, із групою, що навчається, де викладач подає інформацію у вигляді теоретичного матеріалу. Можливо, такий підхід до навчання може бути ефективним при навчанні основних предметів, проте вкрай недосконалий при навчанні практичним (клінічним) навичкам.

Найбільш ефективним підходом до передачі нової інформації слухачам $€$ інтерактивне навчання, тобто навчання в процесі практики. Це більше, ніж просто практика. Це навчання через рефлексію (осмислення) власних дій. Коли фахівець щось робить, то не завжди замислюється над тим, як він це робить. Для того щоб використовувати накопичений досвід, ми маємо відстежувати свої дії та вміти аналізувати їх. Крім того, під час інтерактивного навчання можливо відстежувати досвід інших людей, з різним світосприйняттям, отримувати додаткову інформацію, аналізувати, моделювати ситуації, спільно шукати шляхи вирішення різних питань. Інтерактивні методики дають змогу задіяти не тільки розум людини, а також іï почуття, емоції та спонукати до творчості. Це вимагає високого рівня фахових знань викладачів, які мають бути професійно орієнтованими та реалізуватися 3 використанням усіх сучасних дидактичних прийомів.

Поняття "освіта дорослих "(adult education) охоплює собою комплекс безперервних процесів навчання - як формального, так і спектр його неофіційних форм та різновидів. За його допомогою дорослі люди розвивають свої здібності, збагачуються знаннями, удосконалюють професійні кваліфікації або ж використовують їх у новому напрямку. Система наскрізної безперервної підготовки медичних кадрів в Україні базується на основних міжнародних вимогах до етапів, тривалості, забезпечення якості, що визначені ВОО3 та Світовою федерацією медичної освіти. Процеси безперервної освіти розуміються тепер не тільки як “навчання протягом життя” (lifelong learning), але й як "навчання шириною в життя" (lifewide learning). Останнє акцентує увагу на розмаїтості видів освіти (формальній, неформальній, інформальній). Освіта протягом життя покликана підвищувати рівень загальних знань і розширювати можливості участі громадян у культурній, соціальній іполітичній діяльності країни. Вона повинна робити внесок у подальшу демократизацію суспільства, а також сприяти посиленню позиції людини в професійній діяльності. Вона стає усе більш важливою сферою освітніх послуг. При цьому людина перетворює освітні потенціали суспільства в дієві фактори свого розвитку.

Сьогодні у багатьох країнах реалізується перехід від кваліфікаційної моделі фахівця до компетентностної, при цьому вважається, що компетенція — це єдність професійних і позапрофесійних знань, нави- 
чок, настанов і ціннісних орієнтирів. Кваліфікація описує функціональну відповідність між вимогами професії і метою освіти, а компетентність включає можливості особистості діяти адекватно у білыш широких сферах, тобто у соціумі.

Андрагогічна модель навчання медичних працівників відповідає головним принципам освіти дорослих - результативності, гарантії задоволення потреб, оволодіння уміннями, відпрацювання навичок до рівня автоматизму, розуміння професійних або загальнолюдських явищ, розширення кругозору, зміцнення глибинних ціннісних орієнтацій.

У світлі проблем навчання дорослих людей особливої популярності набула циклічна чотириступінчаста емпірична модель процесу навчання і засвоєння людиною нової інформації (Experiential Learning Model), що запропонована David A. Kolb (1984) і його колегами. Люди навчаються одним 3 чотирьох способів: 1) через досвід; 2) через спостереження і рефлексію; 3) за допомогою абстрактної концептуалізації; 4) шляхом активного експериментування - віддаючи одному з них перевагу перед останніми. Отже, процес навчання, згідно з циклом Д. Колба, може бути розпочатим з будь-якої стадії і продовжуватися до того часу, доки не стане набутою певна навичка.

Основна частина. У процесі навчання більш за все турбують якісні показники. На це можливо впливати через вміння викладачів використовувати весь арсенал педагогічних методик та відчувати, яка 3 них більш принадна при певних обставинах. Як вказує багаторічний досвід, найкраще викладання перебігає через активне залучення всіх слухачів з різноманітними стилями навчання. Крім того, це дає можливість відкривати та розширювати інші канали отримання інформаціі. Викладач має таким чином побудувати свої заняття, щоб зацікавити всіх учасників, охопити всі чотири стадії, які у сукупності складуть цикл навчання від практики до практики. Добре побудований курс приводить до нарощування знань та навичок учасниками навчання. Без повторення навички забуваються. В останні десятиріччя основним завданням, яке ставлять Міністерство охорони здоров'я і Міністерство освіти і науки України перед закладами післядипломної освіти, є суттєве підвищення професійно-практичної підготовки слухачів. Лікар має навчитись спеціальності. Вирішенню цієї проблеми присвячене читання лекційного курсу, проведення семінарських і практичних занять.

Лекція є послідовним викладенням наукових та клінічних даних і висвітлення на цій основі новітніх досягнень вітчизняної і світової науки. Відомо, що залежно від виду циклу курс лекцій може бути сис- тематичним, спеціальним або можуть бути прочитані вибрані розділи. Ми вважаємо, що найбільш доцільним на циклах первинної і вторинної спеціалізації з будь-якого фаху є читання систематичного курсу лекцій, який передбачає викладення в строгій послідовності і прийнятності основних питань, які входять в начальний план і програму циклу, при цьому кожна наступна лекція базується на попередній і логічно з нею пов' язана. На циклі спеціалізації доцільним вважається виділення близько $20 \%$ навчальних годин на лекції від загального об' єму навчальних занять. При проведенні циклу спеціалізації бажано читання таких видів лекцій: вступна, тематична, оглядова, комплексна, заключна і проблемна. Якщо навіть на лекції не буде викладений весь матеріал, то слухач має змогу поповнити свої знання через Інтернет.

Найбілыше значення в забезпеченні якості професійно-практичної підготовки ми надаємо проведенню практичних і семінарських занять. Семінар є одним 3 найбільш ефективних навчальних занять, який сприяє більш глибокому і детальному засвоєнню предмета, навичок самостійної роботи з літературними джерелами, привчає до наукової роботи. Метою семінару є підвищення активності слухачів у вивченні предмета, спонукання їх до пошуку літератури та іiі самостійного вивчення під керівництвом викладача. Тому необхідна попередня, обов'язкова, самостійна підготовка слухачів до цього виду заняття. Розрізняють такі види семінарів: семінар-колоквіум, семінар-дискусія, семінар-конференція, семінар 3 клінічного розбору хворих, семінар з обміну досвідом роботи, семінар з обговорення контрольних робіт, семінар-екскурсія.

Найбільш доцільною формою семінару на циклі первинної і вторинної спеціалізації ми вважаємо семінариколоквіуми, семінари-конференції, семінари з клінічного розбору хворих, семінар-конференція, семінар-екскурсія та ін. При проведенні семінарів-колоквіумів викладач має змогу визначити рівень теоретичних знань слухача 3 відповідної теми, знання алгоритму обстеження, семіотики захворювань та ін. Семінарекскурсія дозволяє ознайомити слухачів з сучасними лікувально-діагностичними, особливо в профільних НДІ, методиками дослідження, зокрема - інтервенційними. Дещо інші завдання стоять перед слухачами при проведенні семінару-конференції на визначенутему. Підготовка доповіді слухачем під керівництвом викладача вчить лікаря роботи 3 джерелами літератури (в т. ч. і електронними), вміння виділити основне і другорядне, ораторського мистецтва. Природно на циклі спеціалізації використовуються і інші семінари, особливо контролюючого характеру. 
Стосовно семінарських занять на циклі ТУ переважними їх формами мають бути: семінар-колоквіум, семінар-дискусія, семінар-конференція, семінар по клінічному розбору хворих, семінар по обміну досвідом роботи, семінар-екскурсія. Ми вважаємо особливо цінним проведення семінарів по обміну досвідом роботи, що дасть змогу поширити передовий досвід роботи на інші лікувальні заклади, а деяким слухачам надати рекомендації щодо покращення їх роботи.

Проведення практичних занять має відбуватись на всіх циклах у лікувально-профілактичних закладах, де $\epsilon$ сучасна високотехнологічна апаратура та контингент хворих, який відповідає темі практичного заняття. 3 нашої точки зору, при навчанні в інтернатурі на практичних заняттях більшу увагу слід приділяти вивченню анатомо-фізіологічних особливостей різних органів і систем, а також лікувально-діагностичних підходів 3 метою досконалого оволодіння різноманітними методиками дослідження.

Загальновідомим є той факт, що підготовка найбільш кваліфікованих лікарів відбувається шляхом навчання в клінічній інтернатурі. Ми вважаємо, що програма навчання ординатора має бути розбитою на окремі модулі. Під час вивчення окремих модулів клінічний ординатор для оволодіння практичними навичками має працювати у відповідних відділеннях та кабінетах спеціалізованих лікувальних закладів.

Теоретичний розділ навчання клінічного ординатора має бути побудований, на наш погляд, за тьюторською системою навчання. Вперше елементи тьюторської системи навчання були впроваджені в Оксфордському і Кембріджському університетах в XIV ст. Тьютор (англ. tutor, від лат. tutor - спостерігаю, піклуюсь) - педагог-наставник, який у навчальний час займається викладацькою діяльністю, а після занять проводить виховну роботу з декількома учнями, керує їх самостійною навчальною роботою, науковими пошуками та ін. Тьюторська система у багатьох вищих навчальних закладах Англії вирізняється порівняно високою ефективністю, вона спрямована на виховання інтелектуальної еліти. Тому ми вважаємо доцільним прикріплення 2-3 клінічних ординаторів на весь термін навчання до одного викладача 3 метою забезпечення високого рівня їх підготовки. Це дасть змогу забезпечити не тільки високий рівень теоретичної і практичної підготовки, а й забезпечити його розвиток як особистості.

Найбільш цінним, на нашу думку, при проведенні навчання клінічних ординаторів і лікарів на циклах тематичного удосконалення $\epsilon$ проведення майстеркласів, що $є$ одним з прикладів професійної педагогіч- ної майстерності викладача, побудованої на високому професіоналізмі, що приносить бажані виховно-освітні результати. Сьогодні активно впроваджувана в практичну педагогіку технологічна парадигма розвитку професіоналізму означає здатність педагога точно формулювати виховно-освітні завдання і логічно послідовно, найбільш оптимально їх вирішувати.

Культура презентації професійного методичного досвіду викладача $\epsilon$ певним результатом його професійної майстерності. Проведення майстер-класу має мати ознаки інноваційності, причому інноваційності не спонтанно емпіричної, а такої, яка характеризується обдуманістю свого професійного досвіду, його системною пропрацьованістю, вивіреністю до рівня технологічно послідовного алгоритму педагогічних дій, які мають привести до раніш задуманого виховно-освітнього результату. Навіть викладачам необхідно постійно навчатися, в т. ч. і один в одного. I кращим заходом буде взаємообмін професійним досвідом, взаємонавчання, взаємовдосконалення своєї виховної і навчальної діяльності. Оптимальною формою взаємонавчання як для викладачів, так і для слухачів, і є майстер-клас. Це форма заняття, в якій сконцентровані такі характеристики: виклик традиційній педагогіці, особистість педагога 3 новим мисленням, не повідомлення знань, а спосіб самостійної їх побудови за допомогою всіх учасників заняття 3 урахуванням плюралізму думок тощо. При проведенні майстер-класу необхідні малі групи слухачів, щоб всі учасники мали змогу обмінюватись думками, треба створити умови для включення всіх слухачів в активну діяльність, необхідною $є$ постановка проблемної задачі і вирішення іï через моделювання різних ситуацій, при цьому форми, методи і технології роботи мають пропонуватись, а не нав'язуватись. Алгоритм проведення майстер-класу повинен будуватись на таких компонентах: виділення проблеми - панель - об' єднання в групи для вирішення проблеми - робота 3 матеріалом - представлення результатів роботи - обговорення і коректування результатів роботи.

Інноваційною формою проведення був також Junior Image Interpretaion Quizzes. Суть його полягає у змаганні двох команд - аудиторії і команди з 4 молодих фахівців - ареопагу (ареопаг - група авторитетних осіб, які зібралися для розв'язання яких-небудь питань), яка виступала проти аудиторії в залі. Суть цього полягає в тому, що модератором надається коротка історія хвороби пацієнта з певними клінічними висновками і 4 варіанти відповідей у вигляді фрагментів медичної документації, зображень (рентгенограм і КТ). Аудиторії пропонувалось визначити, яка 